\title{
Combining stable isotope analyses and geolocation to reveal kittiwake migration
}

\author{
Jacob González-Solís ${ }^{1, *}$, Maria Smyrli ${ }^{1}$, Teresa Militão ${ }^{1}$, David Gremillet ${ }^{2,3}$, \\ Torkild Tveraa ${ }^{3,4}$, Richard A. Phillips ${ }^{4,5}$, Thierry Boulinier ${ }^{2}$ \\ ${ }^{1}$ Institut de Recerca de la Biodiversitat i Departament de Biologia Animal, Universitat de Barcelona, 08028 Barcelona, Spain \\ ${ }^{2}$ Centre d'Ecologie Fonctionnelle et Evolutive, CNRS-UMR 5175, Montpellier, France \\ ${ }^{3}$ Percy FitzPatrick Institute, DST/NRF Centre of Excellence, University of Cape Town, Rondebosch 7701, South Africa \\ ${ }^{4}$ Department of Arctic Ecology, NINA, Tromsø 9296, Norway \\ ${ }^{5}$ British Antarctic Survey, Natural Environment Research Council, High Cross, Madingley Road, Cambridge CB3 0ET, UK
}

\begin{abstract}
Determining migratory strategies of seabirds is still a major challenge due to their relative inaccessibility. Small geolocators are improving this knowledge, but not all birds can be tracked. Stable isotope ratios in feathers can help us to understand migration, but we still have insufficient baseline knowledge for linking feather signatures to movements amongst distinct water masses. To understand the migration strategies of kittiwakes Rissa tridactyla and the link between stable isotopes in feathers and the areas in which these were grown, we tracked 6 kittiwakes from Hornøya, Norway, with light level geolocators over 1 yr. Then we analysed the stable isotopes of carbon and nitrogen in their 1st and 7th primary feathers as well as in the 1st, 3rd, 5th, 7th and 10th primaries of 12 birds found freshly dead in the same breeding colony. After breeding, all tracked birds moved east of the Svalbard Archipelago and subsequently migrated to the Labrador Sea. Thereafter, birds showed individual variation in migration strategies: 3 travelled to the NE Atlantic, whereas the others remained in the Labrador Sea until the end of the wintering period. Changes in stable isotope signatures from the 1st to the 10th primary feathers corresponded well to the sequence of movements during migration and the area in which we inferred that each feather was grown. Thus, by combining information on moult patterns and tracking data, we demonstrate that stable isotope analysis of feathers can be used to trace migratory movements of seabirds.
\end{abstract}

KEY WORDS: Intrinsic markers · Tracking · Seabirds · Wintering grounds · Black-legged kittiwake Resale or republication not permitted without written consent of the publisher

\section{INTRODUCTION}

After the end of the breeding period, many seabirds must combine the requirements to migrate to more productive waters, to replace feathers and to rebuild body reserves in preparation for the subsequent reproductive season. Although migration movements and moulting strategies are often studied independently, determining their relationships could be the key for better understanding of migratory connectivity and carry-over effects from one season to another (Marra et al. 1998). The study of feathers provides a unique opportunity to trace migratory movements through analyses of intrinsic markers, including stable isotopes, without requiring the recapture of individuals: once fully formed, feathers become metabolically inert, with no further chemical exchange with body constituents, maintaining an isotopic record of diet composition during the period of formation (Bearhop et al. 2002).

If moulting birds move among isotopically distinct biomes, feathers grown in each area may differ in their isotopic signatures, potentially providing spatial information on dispersive and migratory movements (Hobson 2005, Furness et al. 2006, Quillfeldt et al. 2010a). Stable isotope analysis has been used increasingly to investigate migratory movements, particularly in ter- 
restrial birds, as isotopic ratios on land show natural patterns of geographic variation (Hobson \& Wassenaar 2008). Applying the same principles to marine vertebrates can also be reliable, but it is less straightforward because of the dynamic nature of the marine ecosystem (Graham et al. 2010). Nevertheless, there is a clear latitudinal trend in $\delta^{13} \mathrm{C}$ in the Southern Ocean between 40 and $80^{\circ} \mathrm{S}$, which has been used to determine the major wintering areas used by a variety of seabirds (Quillfeldt et al. 2005, Cherel \& Hobson 2007, Phillips et al. 2009) and to develop an interpolated map of the regional isotopic landscape or 'isoscape' (Quillfeldt et al. 2010b). In other oceans, however, relationships between the isotopic signatures and the area in which tissues were synthesised need to be properly validated. For example, in a recent study of a pelagic seabird with known moulting patterns, stable isotopes ratios in feathers from tracked birds segregated according to the breeding and wintering areas where they were assumed to have grown (Ramos et al. 2009). Once such links have been established, intrinsic markers from specific feathers can potentially be used to assign birds to their population of origin, staging or wintering area (Oppel \& Powell 2008). This knowledge is important not only to study migratory connectivity, seasonal interactions and their influence on population dynamics, but also to investigate the impacts of human activities. For instance, intrinsic markers can help assign the origin of birds killed in fisheries or by offshore wind farms or oil spills, which is essential for evaluating impacts on the dynamics of affected populations (Gómez-Díaz \& González-Solís 2007).

In this study, we used light level geolocators to track the migration of black-legged kittiwake Rissa tridactyla and to relate their migratory movements to differences in isotopic signatures of feathers moulted in different areas. The black-legged kittiwake is a small gull with a northern circumpolar distribution. Breeding populations of kittiwakes have been the subject of intensive long-term monitoring programs in many areas, including the UK, France, Alaska and Norway (Aebischer \& Coulson 1990, Danchin et al. 1998, Barrett 2001, Gill et al. 2002, Frederiksen et al. 2004, Sandvik et al. 2005, Wanless et al. 2007, Kildaw et al. 2008). Although these programs have provided detailed demographic and behavioural information from widely-separated populations, very little information is available about individual movements outside the breeding season. Ring recoveries indicate that eastern European populations winter in both the eastern and western North Atlantic (Barrett \& Bakken 1997, Nikolaeva et al. 1997). Light level geolocation (Global Location Sensing, Wilson et al. 1992), has been widely used in seabirds ranging from terns to large albatrosses (Phillips et al. 2007, González-Solís et al.
2009, Egevang et al. 2010). The information on spatial and temporal patterns of migratory movements that these geolocators provide can potentially be related to moulting patterns. These patterns are well known in kittiwakes, although they are mainly based on southern populations and therefore the whole moulting schedule for northern populations is probably a few weeks delayed. In general, adults moult primary feathers (P) from May to December (Olsen \& Larsson 2004). The innermost primary (P1) is normally moulted from late May to mid July. Generally, P3 to P4 are moulted from late July to mid-August, P5 to P7 would be renewed from mid-August to mid-September and P8 to P10 from mid September to late October, although retarded birds can moult P10 until December or January (Olsen \& Larsson 2004).

The specific aims of this study were to (1) determine the general spatial and temporal patterns of the migratory movements of kittiwakes from Norway; (2) assess individual differences in migration strategies; and (3) link the isotopic signatures of feathers to the areas where the feathers are inferred to be grown, by combining the tracking information obtained by the geolocators with the timing of moulting described in the literature. This information should ultimately allow the assignment of untracked birds to specific staging and wintering areas, based on isotopic analyses of their feathers.

\section{MATERIAL AND METHODS}

Study species. The black-legged kittiwake is a common breeding species in the arctic and boreal zones. Kittiwakes are small, surface feeders, with little 'spare time' in their activity budget and a limited capacity to switch prey, making them particularly vulnerable to changes in food availability (Regehr \& Montevecchi 1997, Furness \& Tasker 2000). The Norwegian population has declined rapidly since 1980, and the black-legged kittiwake is now categorized as vulnerable on the Norwegian Red List (Barrett 2007). In the North Sea, and particularly in colonies in southeast Scotland and northeast England, the breeding population has also been declining since the early 1990s and kittiwakes are now of conservation concern in the UK (Frederiksen et al. 2004). Several studies indicate that this species is dispersed widely across the North Atlantic and the coast of Europe (Holgersen 1961, Coulson 1966, Barrett \& Bakken 1997, Nikolaeva et al. 1997, Bogdanova et al. in press), with the majority of ringed birds recovered from September to November in Greenland, Newfoundland and Barents Sea, and in the winter (December to February) also in the Faroes, Bay of Biscay and North Sea (Barrett \& Bakken 1997. Nikolaeva et al. 1997). 
Global Location Sensing tracking. We deployed 10 geolocators in May 2008 on breeding kittiwakes from the Hornøya colony ( $\mathrm{N}$ Norway; $70.39^{\circ} \mathrm{N}, 31.16^{\circ} \mathrm{E}$ ). We used $1.5 \mathrm{~g}$ geolocators (Mk14; British Antarctic Survey, UK) wrapped with a piece of self-amalgamating tape and attached to a Darvic ring with a single cable tie. After 1 yr, in May 2009, birds were recaptured while breeding and loggers retrieved. We recovered 9 out of 10 geolocators $(90 \%)$, but could only download data from 6 units because of water ingress. The geolocators had an internal clock and measured light levels every $1 \mathrm{~min}$, recording the maximum reading within a 10 min interval (Afanasyev 2004). Since each location on the planet has a unique combination of time of sunrise and photoperiod, 2 positions per day (one corresponding to local noon and the other to local midnight) can be inferred with an average accuracy of $\sim 200 \mathrm{~km}$ (Phillips et al. 2004). Positions were calculated using TransEdit and BirdTracker (British Antarctic Survey) by inspecting the integrity of the light curve day by day and fitting dawn and dusk times. To filter unrealistic positions, we removed (1) those obtained from light curves showing interferences at dawn or dusk; (2) those with a speed index $>40 \mathrm{~km} \mathrm{~h}^{-1}$, as calculated by the root of the square speed average of the segments formed with the 2 preceding and the 2 following positions; and (3) those within the 30 closest days to the equinoxes. Dates of arrival and departure from different areas were determined visually. Dates of departure were considered to be the first day that the bird's location was outside the cluster of positions of the previous days (corresponding to the breeding, staging or wintering areas), and followed by directed movement away from this area. Similarly, arrival dates were considered to be the first day the bird entered that cluster of positions, preceded by a directed movement towards that area. Moreover, we considered postnuptial migration as the longest migratory movement from a staging area near the breeding colony to the main non-breeding grounds, where they spent most of their non-breeding period.

Each geolocator also tested for immersion in saltwater every $3 \mathrm{~s}$ and recorded the number of such immersions in each 10 min period as a value ranging from 0 (entirely dry) to 200 (entirely wet). This information was used to reconstruct the general activity budget, i.e. the percentage of time spent flying (during migration, when birds are always at sea) or resting on the sea surface.

To check whether kittiwakes used areas covered by ice, we obtained information on the monthly extension of ice in the Barents and Labrador Seas during the study period from ftp://sidads.colorado.edu/ DATASETS/NOAA/G02135/shapefiles/ (Fig. 1).
Feather sampling and stable isotope analyses. We sampled the primary feathers because their moult pattern is well known and less variable than for other parts of the plumage (Olsen \& Larsson 2004). Moreover, to confirm moulting patterns described in the literature, we searched for pictures of kittiwakes that included the date and location where these were taken and where the details of the moulting stage was visible. An example of the collected pictures can be seen in Figs. S1-S6 in Supplement 1 at www.int-res.com/ articles/suppl/m435p251_supp.pdf. We sampled the whole P1, P3, P5, P7 and P10 of 12 freshly dead kittiwakes (presumably killed by predators) collected in Hornøya in May 2008. We also sampled P1 (except the calamus) and P7 (only the tip) of the 6 tracked kittiwakes in May 2009, i.e. after 1 yr of tracking. The sampling protocol for the tracked birds was reduced in terms of the number and extent of feathers in order to minimize potential detrimental effects of reduced wing area on flight performance. Since primary feathers are moulted from May to December, the sampled feathers were from the same generation and grown the year before collection. The time a specific kittiwake feather takes to grow is unknown, but based on the mass of kittiwakes (0.330 to $0.484 \mathrm{~kg}$, Jaeger et al. 2009), we estimated flight feathers grow $\sim 4.7$ to $5 \mathrm{~mm} \mathrm{~d}^{-1}$ (Rohwer et al. 2009), and therefore the growing period of a primary feather from the insertion until the tip may vary from 22 to $23 \mathrm{~d}$ for the short primaries (e.g. P1) and from 43 to $46 \mathrm{~d}$ for the long primaries (e.g. P10).

Feathers were analyzed for $\delta^{15} \mathrm{~N}$ and $\delta^{13} \mathrm{C}$ signatures. All feathers were washed in a $0.25 \mathrm{M}$ sodium hydroxide solution, rinsed thoroughly in distilled water to remove any surface contamination and dried in an oven at $40^{\circ} \mathrm{C}$ to constant mass. The feathers were ground to a fine powder in a cryogenic impact grinder (Freeser/mill Spex Certiprep 6750; Spex) operating at liquid nitrogen temperature. Subsamples of 0.36 to $0.39 \mathrm{mg}$ of feather powder for carbon and nitrogen analyses were weighed to the nearest $\mu \mathrm{g}$, placed into tin capsules and crimped for combustion. Samples were oxidized in a Flash EA1112 and TC/EA coupled to a stable isotope mass spectrometer Delta $\mathrm{C}$ through a Conflo III interface (ThermoFinnigan), where $\delta^{13} \mathrm{C}$ and $\delta^{15} \mathrm{~N}$ signatures were determined. Isotope ratios are expressed conventionally as $\delta$ values in ppt (\%o) according to the following equation:

$$
\delta X=\left[\left(R_{\text {sample }} / R_{\text {standard }}\right)-1\right] \times 1000
$$

where $X(\%)$ is ${ }^{13} \mathrm{C}_{1}{ }^{15} \mathrm{~N}$, and $R$ are the corresponding ratios ${ }^{13} \mathrm{C} /{ }^{12} \mathrm{C}$ and ${ }^{15} \mathrm{~N} /{ }^{14} \mathrm{~N}$, related to the standard values: $R_{\text {standard }}$ for ${ }^{13} \mathrm{C}$ is Pee Dee Belemnite (PDB), for ${ }^{15} \mathrm{~N}$ is atmospheric nitrogen (AIR). The isotopic ratio mass spectrometry facility at the laboratory of the Serveis 
a
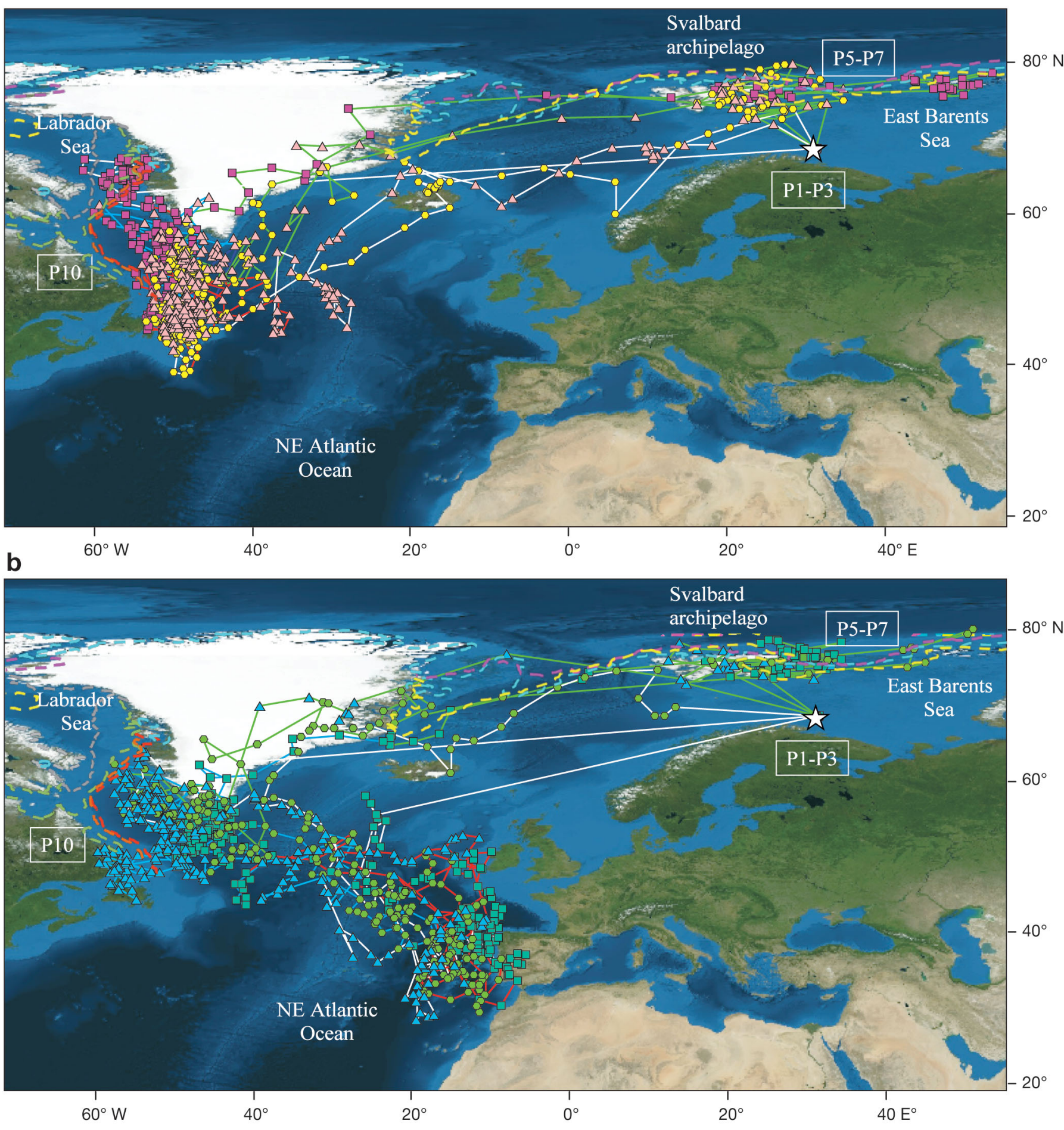

Fig. 1. Rissa tridactyla. Post-breeding dispersal and migratory movements of 6 kittiwakes from the Hornøya breeding colony (white star) tracked with light level geolocators (GLS units). Two distinct migration strategies: kittiwakes remaining (a) from Nov-Feb on the Labrador Sea and (b) the first half of this period in the Labrador Sea but the second half moving to the NE Atlantic. Colour and shape of symbols: different birds. Solid lines: individual tracks in Aug-Oct (green); Nov-Dec (blue); Jan (red); Feb-Mar (white). Dashed lines: monthly extent of sea ice in Aug 2008 (blue), Sep 2008 (pink), Oct 2008 (yellow), Nov 2008 (grey), Dec 2008 (green), Jan 2009 (orange) and Feb 2009 (red). Prenuptial migration is not well defined in most birds due to the proximity of the spring equinox (see 'Materials and methods'). Positions on land are inaccuracies of the geolocation method. Text boxes: inferred moulting areas for each feather, as indicated by the timing of moulting described in the literature (see also Supplement 1, Figs. S1-S6): P1 = first primary feather, etc. For clarity, dashed lines in Svalbard Sea are shown only for the months that the birds were in this area (Aug-Oct) 
Cientificotècnics of the University of Barcelona (Spain) applies international standards (IAEA CH7, IAEA CH6 and USGS 40 for C, IAEA N1, IAEA N2 and IAEA $\mathrm{NO}_{3}$ for $\mathrm{N}$ ), all of them inserted every 12 samples to calibrate the system and compensate for any drift over time. Replicate assays of standard materials indicated measurement errors of \pm 0.1 and $\pm 0.2 \%$ for carbon and nitrogen respectively, but these are likely underestimates of true measurement error for complex organics like feathers.

Statistical analysis. Before statistical analyses, we checked for normality of $\delta^{13} \mathrm{C}$ and $\delta^{15} \mathrm{~N}$ signatures and activity data using the Kolmogorov-Smirnov test. As no severe deviations from normality were found, we used parametric tests throughout. Subsequently, to check for isotopic differences among the 5 primary feathers analysed from kittiwakes found dead in Hornøya, we used ANOVA for repeated measures (Wilks's lambda statistic) in which primary sequence was treated as a within-subject factor. Pairwise comparisons between feathers were analysed using Bonferroni corrections. All statistical procedures were performed using SPSS 15.0 (2006) assuming a significance level of $\mathrm{p}<0.05$. Results are presented as means $( \pm \mathrm{SD}$, range).

\section{RESULTS}

\section{Tracking data}

The 6 tracked kittiwakes left the breeding grounds around August 17 ( $\pm 2 \mathrm{~d}$, August 16-20) and migrated to the area east of the Svalbard Archipelago (between $75-80^{\circ} \mathrm{N}$ and $20-30^{\circ} \mathrm{E}$ ) (Fig. 1a,b; Table 1). All birds spent $55 \mathrm{~d}$ on average $\left( \pm 9 \mathrm{~d}_{i} 43-67 \mathrm{~d}\right)$ in the region; however, 2 individuals moved to the east Barents Sea before the post-nuptial migration: one for almost $3 \mathrm{wk}$ (between $70-80^{\circ} \mathrm{N}$ and $38-56^{\circ} \mathrm{E}$; Fig. 1a pink squares; Table 1) and another for $1 \mathrm{wk}$ (between $77-81^{\circ} \mathrm{N}$ and

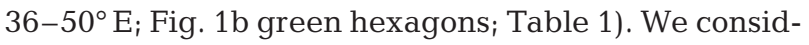
ered this first destination to be a staging area because it is close to the breeding site and is used prior to a long distance migratory movement to the main wintering

Table 1. Rissa tridactyla. Individual migratory patterns of the 6 kittiwakes tracked with geolocators from May 2008 to May 2009 breeding in Hornøya, Norway: dates of departure and arrival, duration of staging and wintering periods, and daily (24 h) time flying and time resting by night (i.e. only when the geolocators did not detect any light) on the sea surface. Each bird and migratory strategy is depicted with the same symbol as in Fig. 1 (open symbols: birds of Fig. 1a; closed symbols: Fig. 1b). Date format is day.month.year

\begin{tabular}{|c|c|c|c|c|c|c|c|}
\hline & $\square$ & 0 & $\triangle$ & $\mathbf{\square}$ & - & $\boldsymbol{\Delta}$ & Mean \pm SD \\
\hline $\begin{array}{l}\text { Daily time resting on the sea } \\
\text { surface during the breeding period (\%) }\end{array}$ & 35.6 & 25.4 & 26.7 & 22.2 & 31.9 & 27.1 & $28.2 \pm 4.8$ \\
\hline Departure from breeding ground & 16.08 .08 & 16.08 .08 & 16.08 .08 & 19.08 .08 & 20.08 .08 & 16.08 .08 & $17.08 .08 \pm 2$ \\
\hline Arrival at Svalbard Archipelago & 18.08.08 & 18.08.08 & 18.08.08 & 21.08 .08 & 22.08 .08 & 18.08.08 & $19.08 .08 \pm 2$ \\
\hline $\begin{array}{l}\text { Staging around Svalbard } \\
\text { Archipelago (d) }\end{array}$ & $\begin{array}{l}66(18 \mathrm{~d} \text { in } \\
\text { E Barents Sea })\end{array}$ & 60 & 57 & 67 & $\begin{array}{l}50(7 \mathrm{~d} \text { in } \\
\text { Barents Sea }\end{array}$ & 54 & $59 \pm 7$ \\
\hline $\begin{array}{l}\text { Daily time flying and time resting } \\
\text { by night while in Svalbard (\%) }\end{array}$ & $\begin{array}{l}31.0 \\
80.3\end{array}$ & $\begin{array}{l}34.7 \\
83.2\end{array}$ & $\begin{array}{l}42.6 \\
64.8\end{array}$ & $\begin{array}{l}26.1 \\
83.1\end{array}$ & $\begin{array}{l}46.2 \\
59.8\end{array}$ & $\begin{array}{l}35.0 \\
83.9\end{array}$ & $\begin{array}{c}35.9 \pm 7.4 \\
75.9 \pm 10.7\end{array}$ \\
\hline Departure from Svalbard Archipelago & 23.10 .08 & 17.10 .08 & 14.10 .08 & 27.10 .08 & 11.10 .08 & 11.10 .08 & $17.10 .08 \pm 7$ \\
\hline $\begin{array}{l}\text { Daily time flying and time resting by } \\
\text { night during postnuptial migration (\%) }\end{array}$ & $\begin{array}{l}33.9 \\
89.4\end{array}$ & $\begin{array}{l}35.8 \\
82.0\end{array}$ & $\begin{array}{l}38.7 \\
83.2\end{array}$ & $\begin{array}{l}38.3 \\
85.5\end{array}$ & $\begin{array}{l}38.2 \\
77.2\end{array}$ & $\begin{array}{l}32.6 \\
83.2\end{array}$ & $\begin{array}{l}36.3 \pm 2.6 \\
83.4 \pm 4.0\end{array}$ \\
\hline Arrival at Labrador Sea & 31.10 .08 & 27.10 .08 & 23.10 .08 & 05.11 .08 & 24.10 .08 & 19.10 .08 & $26.10 .08 \pm 6$ \\
\hline Staging in Labrador Sea (d) & 131 & 103 & 112 & 57 & 39 & 61 & $84 \pm 36$ \\
\hline $\begin{array}{l}\text { Daily time flying and time resting by } \\
\text { night while in Labrador Sea (\%) }\end{array}$ & $\begin{array}{l}27.5 \\
86.9\end{array}$ & $\begin{array}{l}27.8 \\
95.8\end{array}$ & $\begin{array}{l}29.8 \\
95.4\end{array}$ & $\begin{array}{l}29.8 \\
96.1\end{array}$ & $\begin{array}{l}32.8 \\
87.3\end{array}$ & $\begin{array}{l}29.0 \\
90.3\end{array}$ & $\begin{array}{l}29.5 \pm 1.9 \\
92.0 \pm 4.3\end{array}$ \\
\hline Departure from Labrador Sea to the NE Atlanti & tic & - & - & 01.01 .09 & 02.12 .08 & 19.12 .08 & $17.12 .08 \pm 15$ \\
\hline $\begin{array}{l}\text { Daily time flying and time resting by } \\
\text { night while moving to NE Atlantic (\%) }\end{array}$ & $\begin{array}{l}- \\
-\end{array}$ & - & $\begin{array}{l}- \\
-\end{array}$ & $\begin{array}{l}32.4 \\
99.3\end{array}$ & $\begin{array}{l}37.7 \\
92.9\end{array}$ & $\begin{array}{l}29.7 \\
96.4\end{array}$ & $\begin{array}{l}33.3 \pm 4.1 \\
96.2 \pm 3.2\end{array}$ \\
\hline Arrival at NE Atlantic & - & - & - & 09.01 .09 & 15.12 .08 & 15.01 .09 & $02.01 .09 \pm 16$ \\
\hline Staging in the NE Atlantic (d) & - & - & - & 52 & 65 & 47 & $55 \pm 9$ \\
\hline $\begin{array}{l}\text { Daily time flying and time resting by } \\
\text { night while in NE Atlantic (\%) }\end{array}$ & $\begin{array}{l}- \\
-\end{array}$ & $\begin{array}{l}- \\
-\end{array}$ & $\begin{array}{l}- \\
-\end{array}$ & $\begin{array}{l}38.4 \\
93.6\end{array}$ & $\begin{array}{l}35.0 \\
92.3\end{array}$ & $\begin{array}{l}34.7 \\
96.3\end{array}$ & $\begin{array}{l}36.0 \pm 2.1 \\
94.1 \pm 2.0\end{array}$ \\
\hline Departure to breeding grounds & 11.03 .09 & 07.02 .09 & 12.02 .09 & 02.03 .09 & 18.02 .09 & 03.03 .09 & $22.02 .09 \pm 12$ \\
\hline $\begin{array}{l}\text { Daily time flying and time resting by } \\
\text { night during the prenuptial migration (\%) }\end{array}$ & $\begin{array}{l}41.0 \\
79.5\end{array}$ & $\begin{array}{l}35.9 \\
95.3\end{array}$ & $\begin{array}{l}34.8 \\
95.6\end{array}$ & $\begin{array}{l}55.7 \\
81.1\end{array}$ & $\begin{array}{l}38.2 \\
94.9\end{array}$ & $\begin{array}{l}45.5 \\
87.1\end{array}$ & $\begin{array}{l}41.9 \pm 7.8 \\
88.9 \pm 7.4\end{array}$ \\
\hline Arrival at breeding grounds & 22.03 .09 & 24.02 .09 & 24.02 .09 & 09.03 .09 & 07.03.09 & 15.03.09 & $07.03 .09 \pm 10$ \\
\hline
\end{tabular}


area in Labrador and the NE Atlantic in which birds spent a longer period. Kittiwakes left Svalbard around October 17 ( \pm 7 d. October 11-27) and migrated west along the east coast of Greenland (Fig. 1a,b). This movement lasted on average $10 \mathrm{~d}( \pm 1 \mathrm{~d}, 8-13 \mathrm{~d})$ until they reached the Labrador Sea. With one exception, birds did not venture north of $65^{\circ} \mathrm{N}$ in the Labrador Sea, and it seemed that kittiwakes did not venture to areas covered by ice (Fig. 1 dashed lines). Three of the birds stayed in the Labrador Sea for $115 \mathrm{~d}( \pm 14 \mathrm{~d}$, 103-131 d; Fig. 1a; Table 1) until the end of the winter, dispersing from south of Newfoundland to $40^{\circ} \mathrm{N}$, and east in the North Atlantic between $40-50^{\circ} \mathrm{W}$, finally leaving the region around February $19( \pm 17$ d, February 7 -March 11; Fig. 1a white line; Table 1) and arriving in the breeding area on March 4, $2009( \pm 15 \mathrm{~d}$; February 24-March 22). After spending $52 \mathrm{~d}( \pm 12 \mathrm{~d}$, 39-61 d) in the Labrador Sea (Fig. 1b; Table 1), 3 birds moved southwards, reaching the Azores and Canary Islands (mainly after January; Fig. 1b; Table 1) and either dispersed to-and-fro in the North Atlantic Ocean or stayed around the west coast of the Iberian peninsula and Ireland for $55 \mathrm{~d}\left( \pm 9 \mathrm{~d}, 47-65 \mathrm{~d}_{i}\right.$ Fig. $1 \mathrm{~b}$ red lines), departing around February $26( \pm 7$ d, February 18-March 3; Fig. 1b white lines; Table 1) and arriving at the breeding area on March 10, $2009( \pm 4$ d; March 7-15). Compared to the high degree of synchrony in the onset of migration, there was a larger variability among individuals in the date of return to the breeding grounds, with birds arriving on average on March 7 ( \pm 10 d, February 24-March 22).

There was no significant difference between the post and the pre-nuptial migration in the percentage of time spent flying (Table 1, Pairwise $t$-test: $t=-1.65$, $\mathrm{df}=5, \mathrm{p}=0.16)$.

\section{Isotope analyses}

Carbon and nitrogen signatures differed significantly among feathers for the birds found dead in Hornøya $\left(\delta^{15} \mathrm{~N}, F_{4,8}=18.36, \mathrm{p}<0.001 ; \delta^{13} \mathrm{C}, F_{4,8}=\right.$ 51.05, $\mathrm{p}<0.001$ ). The general pattern for the ratios of both isotopes in P1 and P3 was found to be significantly greater on average than those in P5 and P7 (Fig. 2). In addition, carbon isotope ratios in P10 were significantly greater than in P7 (Fig. 2). In 3 of the 12 birds, however, carbon and nitrogen isotopes ratios were similar in P1, P3 and P5 (in Fig. 2, the 3 lines depicted in grey), and for one bird, also in P7 (Fig. 2a, grey line with the highest value of carbon isotope ration in P7).

Similar patterns in isotope values of P1 were apparent in 4 of the 6 tracked birds from Hornøya, i.e. carbon and nitrogen signatures fell within the range of the P1 signatures of the dead birds (Fig. 3). However, 2 birds
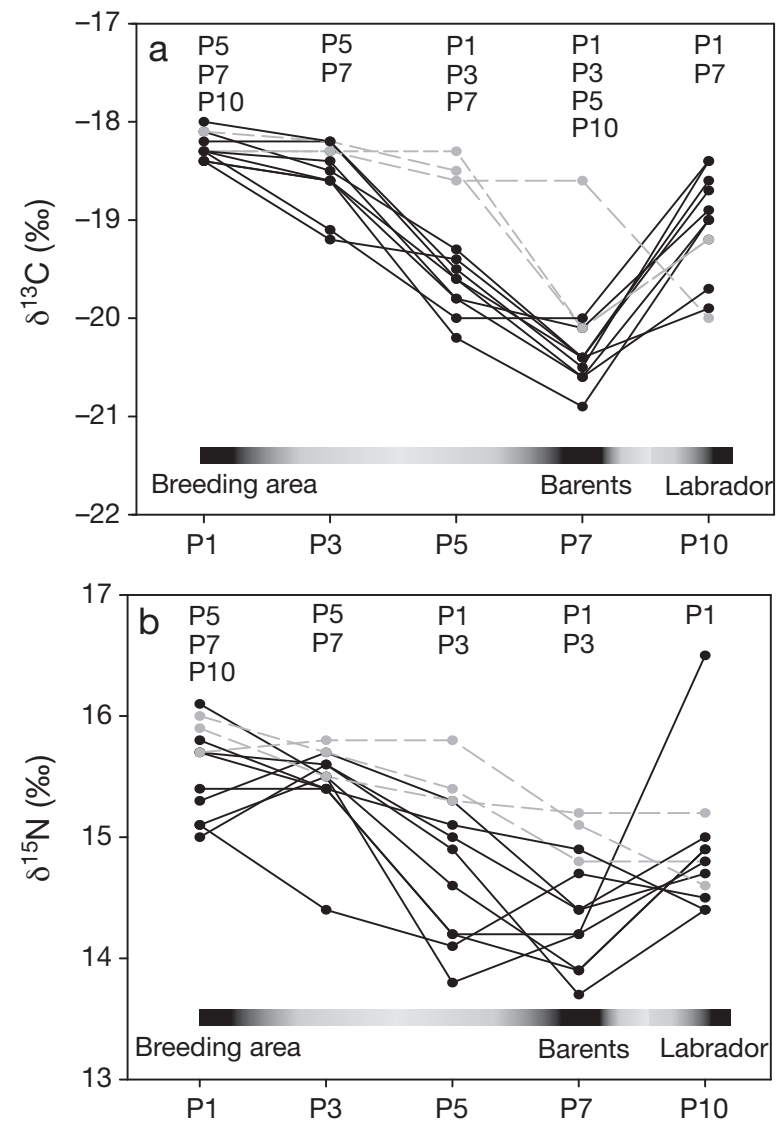

Fig. 2. Rissa tridactyla. (a) Carbon $\left(\delta^{13} \mathrm{C}\right)$ and (b) nitrogen $\left(\delta^{15} \mathrm{~N}\right)$ signatures in 1st (P1), 3rd (P3), 5th (P5), 7th (P7) and 10th (P10) primary feathers from 12 freshly dead kittiwakes collected in Hornøya in May 2008. Each line corresponds to one bird. Grey dots/broken line: 3 possible non- or failed breeders with advanced moult. Significant differences among groups are indicated in the upper part of the figure. Inferred moulting areas for each feather are indicated at the bottom of the figure, as indicated by our tracking data and timing of moulting described in the literature

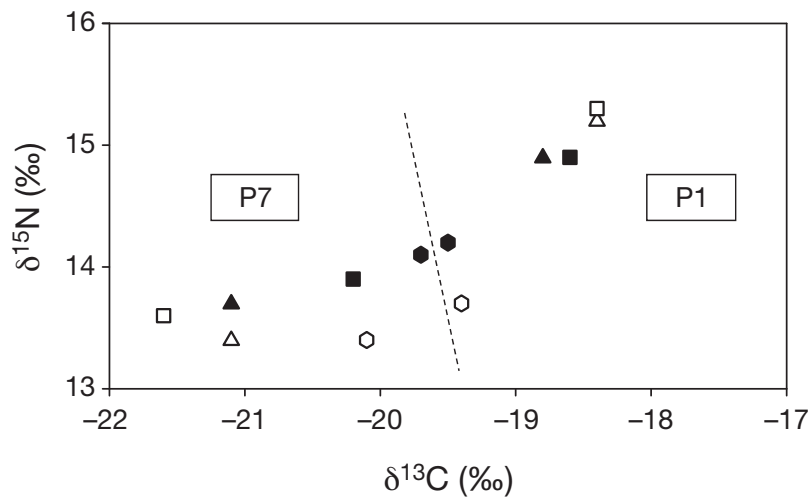

Fig. 3. Rissa tridactyla. Carbon $\left(\delta^{13} \mathrm{C}\right)$ and nitrogen $\left(\delta^{15} \mathrm{~N}\right)$ signatures in 1st (P1) and 7th (P7) primary feathers sampled from the 6 tracked kittiwakes in May 2009, i.e. after 1 yr tracking. Symbols match birds and migratory strategies defined in Fig. 1a (open symbols) and 1b (closed symbols) 
showed depleted signatures, within the range of values for P3 and P5 in the dead birds (Fig. 3 for P1: black hexagon $13.7 \% \delta^{15} \mathrm{~N}$ and $-19.4 \% \delta^{13} \mathrm{C}$; white hexagon $14.2 \% \delta^{15} \mathrm{~N}$ and $-19.5 \% \delta^{13} \mathrm{C}$ ). All tracked birds also showed depleted isotope values in P7 compared to P1, but whereas values from 4 out of 6 birds were close to the range of those of the dead birds, those of one bird were enriched (Fig 3: P7 black hexagon: $14.1 \%$ o $\delta^{15} \mathrm{~N}$ and $-19.7 \% \delta^{13} \mathrm{C}$ ), and those of another were particularly depleted (Fig 3: P7 white square: $13.6 \% \delta^{15} \mathrm{~N}$ and $\left.-21.6 \% \delta^{13} \mathrm{C}\right)$.

\section{DISCUSSION}

Ours is one of the very few studies published to date involving the tracking of long-distance migration in gulls (Muzaffar et al. 2008, Pütz et al. 2008, Bogdanova et al. 2011). After $1 \mathrm{yr}$, we recovered $90 \%$ of the geolocators from the kittiwakes, a figure matching the annual survival rate for the species (Sandvik et al. 2005), suggesting that the impact of the loggers on the birds was negligible. Our results clearly show the migration patterns, staging and main wintering areas for this breeding population, and revealed a remarkable spatial and temporal cohesion in the migratory process as well as the existence of 2 distinct migration strategies (Fig. 1). In brief, after breeding, all birds travelled $\sim 1000 \mathrm{~km}$ north to the Svalbard Archipelago. Subsequently, 2 out of the 6 birds moved to the east Barents Sea for 1 to $3 \mathrm{wk}$ (Fig. 1a pink squares and 1b green hexagons). These 2 individuals also spent most time resting on the sea surface during the breeding period (Table 1), suggesting their movements were related to previous breeding failure. This would be an intriguing parallel with results from a recent study of kittiwakes from a UK population that also found that choice of migration strategy was related to breeding outcome (Bogdanova et al. 2011).

Svalbard is relatively close to the breeding grounds and is in an area of high marine productivity (Mehlum \& Gabrielsen 1993, Weslawski et al. 2000), hence its attractiveness as a staging area where adults can continue feather moult, as well as recover from recent breeding effort, in preparation for a longer distance migration to the main wintering grounds. The staging lasted for $\sim 2 \mathrm{mo}$, after which the birds spent only $10 \mathrm{~d}$ travelling to the Labrador Sea off SW Greenland (Fig. 1 green line; Table 1), where they stayed for at least $40 \mathrm{~d}$ (Fig. 1). The distribution of the birds in Labrador was clearly constrained by the sea ice extent. When birds arrived off Labrador at the end of October or beginning of November 2008, the sea ice extent was north of $72^{\circ} \mathrm{N}$. All birds remained in an ice free area during the winter, i.e. on the eastern side of the Labrador Sea.
This also applies to the only bird that ventured up to $69^{\circ} \mathrm{N}$ in February because this area was not covered by sea ice at that time of the year. This was confirmed by checking the activity of this bird: the daily percentage of time resting on the sea surface when the bird was further north was no different to that recorded during the rest of the winter. Overall, these movements show a consistent directional migration of Norwegian kittiwakes towards the Labrador Sea, which contrast with the previous suggestion based on band recoveries that birds from this population do not target a particular destination (Barrett \& Bakken 1997). In addition, our study provided an unprecedented level of detail on the migratory behaviour of individuals (Fig. 1, Table 1). In general, the results showed a remarkable interindividual consistency in the timing of migration, particularly during the postnuptial period, as well as in the routes and areas selected for staging and wintering. For example, all kittiwakes departed from the colony for Svalbard within a 4 d interval, and left Svalbard for Labrador within a 9 d interval. Moreover, all birds crossed the Atlantic in 8 to $13 \mathrm{~d}$, taking a broadly similar, northerly route during the post-nuptial migration, and returned in a 7 to $17 \mathrm{~d}$ interval during the prenuptial migration. Finally, birds also showed very similar activity patterns during the non-breeding period (Table 1). Nevertheless, we also found 2 distinct migratory strategies in equal proportions: either remaining for the entire winter in the Labrador Sea for 15 to $19 \mathrm{wk}$ (Fig. 1a) or leaving this area after 6 to $9 \mathrm{wk}$ and moving to the NE Atlantic for 5 to $9 \mathrm{wk}$ (Fig. 1b). The use of these alternative migration strategies may be related to the success of the previous breeding season and may have implications for breeding in the following season. Our results suggest that some birds that remained in the Labrador Sea during winter arrived earlier than the birds that moved to the NE Atlantic. If later arrival leads to a similar delay in laying date, there may be consequences for subsequent breeding success. However, this would need to be confirmed by further work with a larger sample of tracked birds (Lindberg \& Walker 2007).

Our study highlights the utility of stable isotope analyses for revealing the migratory movements of seabirds. In the 12 kittiwakes found freshly dead at the study colony, stable carbon and nitrogen isotope ratios in P1 and P3 were significantly greater than in P5 and P7, and rose again by the time that P10 was grown (Fig. 2), suggesting the use of 3 areas during the moulting period. This was corroborated by combining the information obtained from the loggers with the moulting patterns described in the literature and in the pictures that we collected from the internet (see Figs. S1-S6 in Supplement 1). In general, different isotopic signals were associated with the areas where 
the feathers were inferred to be grown: the residency in the breeding (Norway), staging (Svalbard/Barents Sea) and the main wintering area (Newfoundland/ Labrador Sea). The NE Atlantic is the only area that could not be associated with a particular feather isotopic signal, as the kittiwakes had already finished moulting when they moved to this area. The first moulting area corresponds to the breeding grounds, where birds start regrowing their inner primaries towards the end of the breeding season, between May and July, and may have renewed P3 and possibly P4 by late July to mid-August (Olsen \& Larsson 2004; however, see Fig. S3 in Supplement 1). Hence, isotopic signatures in P1 and P3, grown while around the colony, showed enriched $\delta^{13} \mathrm{C}$ compared to P5, P7 and P10, suggesting inshore foraging (Hobson 1999). During the chick rearing period, kittiwakes from Hornøya forage within $27 \mathrm{~km}$ from the breeding colony (Furness \& Barrett 1985), and ranges are even shorter $(<5 \mathrm{~km})$ elsewhere if prey abundance is high (Hamer et al. 1993, Suryan et al. 2002). Lower variability in isotope signatures of P1 and P3 compared to the other primaries probably reflects the constrained distribution and relative reliance of kittiwakes on a few fish species, mainly capelin Mallotus villosus and herring Clupea harengus during the late breeding season and early winter (Barrett \& Krasnov 1996, Barrett et al. 2004, Barrett 2007).

The second moulting area would correspond to the NE Barents Sea around E Svalbard, used by the tracked kittiwakes from mid August to October 27 (Fig. 1). During this period, birds usually moult P5 to P9 (Olsen \& Larsson 2004, see Figs. S1-S6 in Supplement 1). This conclusion is also supported by the low $\delta^{13} \mathrm{C}$ and $\delta^{15} \mathrm{~N}$ found in P7 (Fig. 2). A slightly lower carbon isotope ratio compared to the breeding grounds is also apparent in kittiwake preys as well as in other bird species (see Table S1 in Supplement 2 at www.int-res.com/articles/suppl/m435p251_supp.pdf: Norwegian Sea vs. Barents Sea isotopic signatures of Atlantic Cod Gadus morhua and eider duck Somateria mollissima). Low nitrogen signatures probably reflect the great abundance of lower trophic-level prey locally concentrated in hydrological (tidal) fronts in inner fjords (Weslawski et al. 2006). Indeed, it has been shown that seabirds in the Barents Sea consume more invertebrates than in the Norwegian Sea (Barrett et al. 2002). The increase in variability in isotopic signatures is likely to result from the greater dispersion of individuals compared to their more aggregated distribution during the breeding season, as well as from the consumption of a greater variety of fish (polar cod Boreogadus saida, Liparis sp., Stichaeidae) and invertebrates (euphausiids: Thysanoessa sp.; pelagic amphipods: Parathemisto spp.; polychaetes: Nereis sp.; and pteropods; Lonne \& Gabrielsen 1992, Mehlum \& Gabrielsen 1993).

The third moulting area is likely to correspond to the Labrador Sea, where tracked kittiwakes were present from mid October at least until early December (Fig. 1 blue line). Moult is usually completed by November (see Fig. S6), although in some birds, P10 is not completely regrown until December or January (Olsen \& Larsson 2004; see Figs. S4 \& S5 in Supplement 1). However this moulting pattern should be taken with caution because these are mainly based on populations from southern Scandinavia, whereas kittiwakes from northern populations (e.g. Spitsbergen) begin moulting 1.5 mo later (mid July) than those from more southern localities, such Denmark (late May; Olsen \& Larsson 2004). This possibly means that timing of moulting in northern Norway is delayed by a few weeks compared to the moulting patterns described in the literature. In principle, we might expect birds to migrate from the staging to the main wintering area only after moult is completed, as moulting, migration and reproduction are usually balanced to minimize the overlap in their respective energy demands (e.g. Bridge 2006). However, this is particularly difficult for northern kittiwake populations where the breeding, moulting and migrating calendar is more time constrained due to a short summer. For example, the primary moult of kittiwakes at Bear Island (Northern Norway) is less advanced in July in contrast to birds from Britain, suggesting that many adults do not have enough time to complete moult before departure from the staging areas to the main wintering grounds in October (Meissner 2002). The change between areas before growing P10 is reflected in the increase in carbon isotope ratio of P10 compared to P7 (Fig. 2a). This is probably related to differences in isotopic baseline levels between Svalbard and Labrador, as values in plankton from the upper ocean in Labrador seem to be lower than around Norway (Graham et al. 2010). This is also consistent with the slightly lower carbon isotope ratios of typical preys of kittiwakes in the Barents Sea compared to locations around Newfoundland (see Table S1 in Supplement 2), including some invertebrates (Calanus glacialis and $C$. hyperboreus), and Atlantic and polar cod (Boreogadus saida), although this does not apply to capelin, which is another common prey species. The change in isotopic composition in kittiwake feathers also corresponds to observed differences in isotope signatures of other species of birds, including the eider duck and the little auk (Alle alle blood samples) and even in the muscle of Kittiwake between these areas (see Table S1 in Supplement 2), which would support differences in baseline levels among water masses as a major influence on isotopic variability in the tissues of marine predators. Although P10 is probably mostly grown in Labrador, 
the extended period that long primaries take to be fully grown (from 43 to 46 d) suggests that isotopic signatures of the P10 may also partly integrate signatures from the previous $10 \mathrm{~d}$ trip from the Barents to the Labrador Sea or even from earlier days in the Barents Sea. Indeed, the observed variability in P10 signatures among individuals probably reflects differences in the time period integrated by each individual. The last grown portion of P10 (the basal part of the feather) may reflect the isotopic signatures of the NE Atlantic in those birds that do not remain the entire winter in the Labrador Sea. Since we ground the whole feather to powder, we could not distinguish isotope values in different portions of the P10, but future studies should consider dividing this feather in parts in order to test this hypothesis.

Although most birds showed a similar pattern of change in isotopic signatures of their primaries, 3 out of the 12 dead birds found in Hornøya showed an apparently advanced moult schedule, and probably grew P1 to P7 around the breeding colony, and only P10 in the Svalbard area (Fig. 2 grey dots and broken line). The most likely explanation is that these were non-breeders or failed breeders in the previous season, which are known to start moulting earlier than successful breeders that are energetically constrained by the need to provision chicks (Harris 1971, Walters 1978).

Analyses of P1 and P7 collected from the 6 tracked birds when the loggers were retrieved showed patterns consistent with those found in the dead birds; i.e. $\delta^{13} \mathrm{C}$ and $\delta^{15} \mathrm{~N}$ were higher in $\mathrm{P} 1$ and lower in $\mathrm{P} 7$ (Fig. 3). In one case, however, there was little difference between these 2 feathers; instead, values corresponded with those typically found in the first primary feathers. Since this kittiwake showed a similar timing of migration to the rest of birds, the most plausible explanation is an advancement of the moult following early breeding failure, as suggested by longer periods resting on the sea surface during the breeding season (Table 1). Interestingly, the bird showing the lowest $\delta^{13} \mathrm{C}$ signature in P7 $(-21.6 \%$ o) was the one to disperse further east of Svalbard for $18 \mathrm{~d}$, to waters around Frans Josef Land in the Russian Arctic $\left(80^{\circ} \mathrm{N}, 55^{\circ} \mathrm{E}\right.$; Fig. 1a pink squares). Here, kittiwakes forage extensively on large numbers of pelagic invertebrates forced by tidal currents into shallow water near the shore (Weslawski et al. 1994). This result provides some evidence that use of different staging areas may be traced from isotope signatures of particular feathers grown during the relevant period. A greater sample size and possibly information of birds from other colonies would be needed to confirm this possibility.

In conclusion, our study documented some remarkable spatial and temporal cohesion in kittiwake migra- tion patterns, but also showed 2 distinct migration strategies within the same population, with kittiwakes either remaining all winter in the Labrador Sea, or moving in mid winter to the NE Atlantic. Kittiwakes from the UK also show 2 very different migration strategies (Bogdanova et al. in press). However, differences in migration strategies among populations remain to be determined. Moreover, the present study suggests that Artic ice is an effective barrier for the wintering distribution of kittiwakes. Given current predictions that Artic sea ice extent will continue to shrink over the next years, we expect kittiwakes to change their migration patterns and wintering distribution in the near future. In this context, the deployment of geolocators at multiple sites and over several seasons would provide an excellent opportunity to better understand variability in migration patterns among populations, and also among individual birds in relation to local breeding conditions (Boulinier et al. 2008) and climate change. Combining the information on movements of our tracked birds with that on moult schedule described in the literature, we showed that isotope signatures of primary feathers correspond well with those in the areas in which they were grown, i.e. breeding, staging or main wintering areas. Therefore, our results add to the evidence from recent studies that it is possible to trace the migratory movements of marine predators using intrinsic markers in their tissues. This provides new opportunities for improving knowledge of migratory connectivity and seasonal interactions of marine predators that are currently impossible to track using other methods.

Acknowledgements. We thank E. Gómez-Díaz, K. McCoy and R. Spann for help at different stages of the work. This work benefited from support by the French Polar Institute (IPEV, programme no. 0333), the Centre National de la Recherche Scientifique (CNRS) and through the project CGL2009-11278/BOS from Ministerio de Ciencia e Innovación and Fondos FEDER. We also thank Fylkesmannen i Finnmark and Kystverket (Norway) for allowing us to carry out this work on Hornøya. T.M. was supported by a PhD grant from the Fundação para a Ciência e Tecnologia (SFRH/BD/ 47467/2008).

\section{LITERATURE CITED}

Aebischer NJ, Coulson JC (1990) Survival of the kittiwake in relation to sex, year, breeding experience and position in the colony. J Anim Ecol 59:1063-1071

Afanasyev V (2004) A miniature daylight level and activity data recorder for tracking animals over long periods. Mem Nat Inst Pol Res 58(Spec Issue):227-233

Barrett RT (2001) Monitoring the Atlantic Puffin Fratercula arctica, Common Guillemot Uria aalge and Black-legged Kittiwake Rissa tridactyla breeding populations on Hornoya, northeast Norway, 1980-2000. Fauna Nor 21:1-10

Barrett RT (2007) Food web interactions in the southwestern 
Barents Sea: black-legged kittiwakes Rissa tridactyla respond negatively to an increase in herring Clupea harengus. Mar Ecol Prog Ser 349:269-276

Barrett RT, Bakken V (1997) Movements of kittiwakes Rissa tridactyla ringed in Norway. Ringing Migr 18:25-32

Barrett RT, Krasnov YV (1996) Recent responses to changes in stocks of prey species by seabirds breeding in the southern Barents Sea. ICES J Mar Sci 53:713-722

Barrett RT, Anker-nilssen T, Gabrielsen GW, Chapdelaine G (2002) Food consumption by seabirds in Norwegian waters. ICES J Mar Sci 59:43-57

Barrett RT, Josefsen TD, Polder A (2004) Early spring wreck of Black-legged Kittiwakes Rissa tridactyla in North Norway, April 2003. Atl Seabirds 6:33-45

Bearhop S, Waldron S, Votier SC, Furness RW (2002) Factors that influence assimilation rates and fractionation of nitrogen and carbon stable isotopes in avian blood and feathers. Physiol Biochem Zool 75:451-458

Bogdanova MI, Daunt F, Newel M, Phillips RA, Harris MP, Wanless S (2011) Seasonal interactions in the blacklegged kittiwake: links between breeding performance and winter distribution. Proc R Soc Lond B 278:2412-2418

Boulinier T, McCoy KD, Yoccoz NG, Gasparini J, Tveraa T (2008) Public information affects breeding dispersal in a colonial bird: kittiwakes cue on neighbours. Biol Lett 4:538-540

Bridge ES (2006) Influences of morphology and behavior on wing-molt strategies in seabirds. Mar Ornithol 34:7-19

- Cherel Y, Hobson KA (2007) Geographical variation in carbon stable isotope signatures of marine predators: a tool to investigate their foraging areas in the Southern Ocean. Mar Ecol Prog Ser 329:281-287

Coulson JC (1966) Movements of Kittiwake. Bird Study 13:107-115

Danchin É, Boulinier T, Massot M (1998) Conspecific reproductive success and breeding habitat selection: implications for the study of coloniality. Ecol 79:2415-2428

Egevang C, Stenhouse IJ, Phillips RA, Petersen A, Fox JW, Silk JRD (2010) Tracking of Arctic terns Sterna paradisaea reveals longest animal migration. Proc Natl Acad Sci USA 107:2078-2081

Frederiksen M, Wanless S, Harris MP, Rothery P, Wilson LJ (2004) The role of industrial fisheries and oceanographic change in the decline of North Sea black-legged kittiwakes. J Appl Ecol 41:1129-1139

Furness RW, Barrett RT (1985) The food requirements and ecological relationships of a seabird community in North Norway. Ornis Scand 16:305-313

Furness RW, Tasker ML (2000) Seabird-fishery interactions: quantifying the sensitivity of seabirds to reductions in sandeel abundance, and identification of key areas for sensitive seabirds in the North Sea. Mar Ecol Prog Ser 202:253-264

Furness RW, Crane JE, Bearhop S, Garthe S and others (2006) Techniques to link individual migration patterns of seabirds with diet specialization, condition and breeding performance. Ardea 94:631-638

Gill VA, Hatch SA, Lanctot RB (2002) Sensitivity of breeding parameters to food supply in Black-legged Kittiwakes Rissa tridactyla. Ibis 144:268-283

Gómez-Díaz E, González-Solís J (2007) Geographic assignment of seabirds to breeding origin: combining morphology, genetics, and biogeochemical analyses. Ecol Appl 17:1484-1498

González-Solís J, Felicisimo A, Fox JW, Afanasyev V, Kolbeinsson Y, Munoz J (2009) Influence of sea surface winds on shearwater migration detours. Mar Ecol Prog Ser 391:
221-230

Graham BS, Koch PL, Newsome SD, McMahon CR, Aurioles D (2010) Using isoscapes to trace the movements and foraging behavior of top predators in oceanic ecosystems. In: West JB, Bowen GJ, Dawson T, Tu KP (eds) Isoscapes: understanding movement, pattern, and process on Earth through isotope mapping. Springer, New York, p 299-318

- Hamer KC, Monaghan P, Uttley JD, Walton P, Burns MD (1993) The influence of food supply on the breeding ecology of Kittiwakes Rissa tridactyla in Shetland. Ibis 135: $255-263$

Harris MP (1971) Ecological adaptations of moult in some British gulls. Bird Study 18:113-118

> Hobson KA (1999) Tracing origins and migration of wildlife using stable isotopes: a review. Oecologia 120:314-326

- Hobson KA (2005) Using stable isotopes to trace longdistance dispersal in birds and other taxa. Divers Distrib 11:157-164

Hobson KA, Wassenaar LI (2008) Tracking animal migration with stable isotopes. Academic Press, London

Holgersen H (1961) Über die Wanderungen der norwegischen Dreizehenmöwen Rissa tridactyla (L.). Vogelwarte 21:118-122

Jaeger I, Hop H, Gabrielsen GW (2009) Biomagnification of mercury in selected species from an Arctic marine food web in Svalbard. Sci Total Environ 407:4744-4751

Kildaw D, Irons DB, Buck CL (2008) Habitat quality and metapopulation dynamics of Black-legged Kittiwakes Rissa tridactyla. Mar Ornithol 36:35-45

Lindberg MS, Walker J (2007) Satellite telemetry in avian research and management: sample size considerations. J Wildl Manag 71:1002-1009

Lonne OJ, Gabrielsen GW (1992) Summer diet of seabirds feeding in sea-ice-covered waters near Svalbard. Polar Biol 12:685-692

> Marra PP, Hobson KA, Holmes RT (1998) Linking winter and summer events in a migratory bird by using stable-carbon isotopes. Science 282:1884-1886

> Mehlum F, Gabrielsen GW (1993) The diet of high-arctic seabirds in coastal and ice-covered, pelagic areas near the Svalbard archipelago. Polar Res 12:1-20

Meissner W (2002) Primary moult in Kittiwake. Ornis Nor 25:49-51

Muzaffar SB, Takekawa JY, Prosser DJ, Douglas DC and others (2008) Seasonal movements and migration of Pallas's gulls Larus ichthyaetus from Qinghai Lake, China. Forktail 24:100-107

Nikolaeva NG, Krasnov YV, Barrett RT (1997) Movements of kittiwakes Rissa tridactyla breeding in the southern Barents Sea. Fauna Nor C 20:9-16

Olsen KM, Larsson H (2004) Gulls of Europe, Asia and North America. Helm Identification Guides, London

> Oppel S, Powell AN (2008) Assigning king eiders to wintering regions in the Bering Sea using stable isotopes of feathers and claws. Mar Ecol Prog Ser 373:149-156

Phillips RA, Silk JRD, Croxall JP, Afanasyev V, Briggs DR (2004) Accuracy of geolocation estimates for flying seabirds. Mar Ecol Prog Ser 266:265-272

Phillips RA, Croxall JP, Silk JRD, Briggs DR (2007) Foraging ecology of albatrosses and petrels from South Georgia: two decades of insights from tracking technologies. Aquat Conserv Mar Freshw Ecosyst 17:S6-S21

Phillips RA, Bearhop S, Mcgill RAR, Dawson DA (2009) Stable isotopes reveal individual variation in migration strategies and habitat preferences in a suite of seabirds during the nonbreeding period. Oecologia 160:795-806

Pütz K, Helbig A, Pedersen K, Rahbek C, Saurola P, Juvaste R 
(2008) From fledging to breeding: long-term satellite tracking of the migratory behaviour of a Lesser Black-backed Gull Larus fuscus intermedius. Ringing Migr 24:7-10

Quillfeldt P, McGill R, Furness RW (2005) Diet and foraging areas of Southern Ocean seabirds and their prey inferred from stable isotopes: a review and case study of the Wilson's storm-petrel. Mar Ecol Prog Ser 295:295-304

Quillfeldt P, Voigt CC, Masello JF (2010a) Plasticity versus repeatability in seabird migratory behaviour. Behav Ecol Sociobiol 64:1157-1164

Quillfeldt P, Masello JF, McGill RA, Adams M, Furness RW (2010b) Moving polewards in winter: a recent change in the migratory strategy of a pelagic seabird? Front Zool $7: 15$

Ramos R, Gonzalez-Solis J, Croxall JP, Oro D, Ruiz X (2009) Understanding oceanic migrations with intrinsic biogeochemical markers. PLoS ONE 4:e6236

Regehr HM, Montevecchi WA (1997) Interactive effects of food shortage and predation on breeding failure of blacklegged kittiwakes: indirect effects of fisheries activities and implications for indicator species. Mar Ecol Prog Ser 155:249-260

Rohwer S, Ricklefs RE, Rohwer VG, Copple MM (2009) Allometry of the duration of flight feather molt in birds. PLoS Biol 7:e1000132

Sandvik H, Erikstad KE, Barrett RT, Yoccoz NG (2005) The effect of climate on adult survival in five species of North

Editorial responsibility: Yves Cherel, Villiers-en-Bois, France
Atlantic seabirds. J Anim Ecol 74:817-831

SPSS (2006) SPSS version 15.0.1. SPSS, Chicago, IL

Suryan RM, Irons DB, Kaufman M, Benson J, Jodice PGR, Roby DD (2002) Short-term fluctuations in forage fish availability and the effect on prey selection and broodrearing in the black-legged kittiwake Rissa tridactyla. Mar Ecol Prog Ser 236:273-287

Walters J (1978) The primary moult in four gull species near Amsterdam. Ardea 66:32-47

Wanless S, Frederiksen M, Daunt F, Scott BE, Harris MP (2007) Black-legged kittiwakes as indicators of environmental change in the North Sea: evidence from long-term studies. Prog Oceanogr 72:30-38

- Weslawski JM, Stempniewicz L, Galaktionov K (1994) Summer diet of seabirds from the Frans Josef Land archipelago, Russian Arctic. Polar Res 13:173-181

Weslawski JM, Pedersen G, Petersen SF, Porazinski K (2000) Entrapment of macroplankton in an Arctic fjord basin, Kongsfjorden, Svalbard. Oceanol 42:57-69

Weslawski JM, Kwasniewski S, Stempniewicz L, BlachowiakSamolyk K (2006) Biodiversity and energy transfer to top trophic levels in two contrasting Arctic fjords. Pol Polar Res 27:259-278

Wilson RP, Ducamp JJ, Rees WG, Culik BM, Niekamp K (1992) Estimation of location: global coverage using light intensity. In: Priede IG, Swift SM (eds) Wildlife telemetry. Ellis Horwood, New York, NY, p 131-134

Submitted: April 27, 2010; Accepted: May 26, 2011

Proofs received from author(s): August 15, 2011 